\title{
The politics of agrofuels and mega-land and water deals: insights from the ProCana case, Mozambique
}

\author{
Saturnino M. Borras Jr ${ }^{\mathrm{a}, \mathrm{b} *}$, David Fig ${ }^{\mathrm{c}}$ and Sofía Monsalve Suárez ${ }^{\mathrm{d}}$ \\ ${ }^{a}$ International Institute of Social Studies, The Hague, the Netherlands; ${ }^{b}$ China Agricultural \\ University, Beijing, China; ${ }^{c}$ Environmental Evaluation Unit, University of Cape Town, Cape \\ Town, South Africa; ${ }^{d}$ FoodFirst Information and Action Network International, Heidelberg, \\ Germany
}

\begin{abstract}
This paper examines the politics of large-scale commercial biofuels production and mega-land-water deals, with special reference to the dynamics of changes in land/ water use and property rights and how these impact on the lives and livelihoods of the socio-economically marginalised rural sectors in the countryside. The main argument is that the assumption about existing, available marginal lands is fundamentally flawed. It is demonstrated by examining the ProCana sugar cane ethanol plantation in Gaza province in Mozambique.
\end{abstract}

Keywords: land grabbing; land use; agrofuels/biofuels; Mozambique; ProCana; corporate accountability

\section{Introduction: agrofuels and global land-water grabbing}

The recent realisation about 'peak oil' has renewed interest in liquid agrofuel that had witnessed initial interest in the early 1970s which was then also provoked by the oil crisis. There is a special interest in liquid agrofuel because it is ready for blending with fossil fuel and immediately useable in existing technologies in the global transport sector. Despite ebb and flow in the Brazilian ethanol industry since the early 1970s, it continues to be the world's largest and most technologically advanced sugar cane-based ethanol industry (Wilkinson and Herrera 2010). But it was the recent decision of the United States government to shift much of its corn from grain use for livestock to ethanol to fuel cars together with the European Union policy for mandatory biofuel blending that, combined, have provided the most important context for the global interest in agrofuel. In the United States and European Union there are three main policy narratives that underpin the quest for agrofuel: as a response to climate change (greenhouse gas savings), energy security since many of the sources of fossil fuel are politically hostile or unstable countries, and rural development since the promotion of agrofuel are claimed to promote employment and livelihoods. But even if all currently cultivated lands in the United States and European Union are transformed into biofuel production, it will not be sufficient to meet the growing demands for agrofuel. It is in this context that outsourcing biofuel production has become a key pillar in the emerging global agrofuel complex (Gillon 2010; and Franco et al. 2010).

*Corresponding author. Email: junborras@yahoo.com 
Moreover, the United States and European Union biofuel narratives in particular, and the climate change policy discourse in general, have provoked similar biofuel mandatory blending policies worldwide, with highly uneven processes from one society to the next (e.g., Borras et al. 2010).

The biofuels phenomenon and the interlinked food crisis that hit the world in 20072008 triggered multiple effects in terms of socio-economic and political responses worldwide. One of the immediate effects is 'global land grabbing'. The latter has already been slowly developing for years and should be seen from a historical perspective (McMichael 2009), but the 2007-2008 food and oil crises triggered a faster pace and wider scope, and multiple actors, e.g. China, the Gulf States and South Korea, but also transnational corporations from the West engaged in multiple interests - from agribusiness to biofuels, from finance to biotechnology, from cars to food. The general narrative is that there is a solution to the food and oil crises, and the solution lies in the existence of global reserve agricultural lands that are marginal and under-utilised, and that transforming these lands into zones of food and biofuels production for export would result in a 'positive sum' for societies and not undermine the food security of affected local communities. It will even reinvigorate anaemic rural economies in developing countries because it will generate employment and livelihoods to local people. Klaus Deininger (2011) of the World Bank estimates these available lands to be somewhere between a minimum of 445 million ha and a maximum of 1.7 billion ha, with a significant portion of these located in Africa. In a short period of time, or by the end of 2010, the World Bank reported that 45 million ha of land had already been allocated through mega-land deals, the majority of which are in Africa, although about $70 \%$ of these land investments are not yet in full operation (Deininger (2011; also Cotula et al. 2009). There is a special interest in promoting large-scale industrial sugar cane plantations in Africa in the belief that there is sufficient supply of available, appropriate lands there (Richardson 2010).

There are widespread reports of corruption in these land deals, as well as disruption, displacement and dispossession among rural poor people's communities (e.g. Vermeulen and Cotula 2010). In response, multilateral agencies led by the World Bank have pushed for a regulation of land deals via the so-called 'principles of responsible agricultural investments' or RAI principles (World Bank 2010). Critics such as the United Nations Special Rapporteur for the right to food Olivier De Schutter argue that this will not prevent, but is likely even to facilitate further land grabbing (De Schutter 2010; also Borras and Franco 2010). Supporting De Schutter, $\mathrm{Li}$ (2011) argues that the worst scenario is when capitalist corporations needed the land but not the labour of local people in situations where the dispossessed cannot be absorbed in any productive sectors (industrial or agricultural, in town or country): they become 'surplus people' in very precarious living conditions.

This paper will get its analytical signpost from De Schutter and Li, and argue that that the notion of existing, available marginal lands is fundamentally flawed; investors are looking not only for available lands, but also lands that have sources of water. It will look into the case of Mozambique, and the initial phase in setting up the ProCana sugar cane ethanol project in particular, to explain the point. The fieldwork for this paper was carried out in August-September 2009, and in several shorter visits after that period by the authors, individually and as a group.

\section{Agrofuels and mega-land deals in Mozambique}

Mozambique fits the profile set by mainstream institutions about the narrative on marginal lands: a land-abundant country where taking blocks of under-utilised lands is theoretically 
assumed not to result in livelihood disruption or displacement and the dispossession of local people. Therefore, Mozambique is one of the countries in the world today where agrofuels (ethanol and biodiesel) are currently pursued with great optimism and vigour by transnational corporations, international development agencies and the national government. The Mozambican President, Armando Guebuza, said that 'biofuel development will not dislodge Mozambican farmers from their lands'. According to the Mozambican leader, underutilised or empty lands would be cultivated for biofuels, and the same initiative would 'avoid using lands used for food production'. This statement was declared during the launch of the Central African Mining and Exploration Company (CAMEC) sugarcane ethanol project (popularly known as 'ProCana'), when the London-based company announced it would invest US\$510 million in 30,000 ha of land in Gaza province (BiofuelsDigest 2008).

One of the bases for the optimism on biofuels lies on the current state of agriculture in Mozambique. By 2008, agriculture employed $80 \%$ of the country's population, but contributed less to the country's gross domestic product, at more or less $25 \%$, while the sector contributed $16 \%$ to all exports. Commercial agriculture is not the norm, where agribusiness covers only $3 \%$ of the total cultivated land. Based on this profile, a team of consultants sponsored by the World Bank and the Embassy of Italy prepared a policy study and recommendation to the Ministries of Energy and Agriculture on biofuels for the country, emphasising the availability of under-utilised lands: 'Five million hectares of land are currently under production, and land available for expansion of production ranges from 10 million to as much as 19 million hectares' (Econergy International Corporation 2008, p. 22).

After the initiation of numerous biofuel projects without any policy framework in place (Table 1), in May 2009 the government of Mozambique finally approved a new 'Policy and Strategy for Biofuels' (Government of Mozambique 2009). It is the result of the priority set by the Ministry of Energy to develop a national energy sector, reduce oil imports and enhance energy security (Econergy International Corporation 2008). It is the main policy instrument that will govern the production and exchange of biofuels in the country. The policy declares that the biofuel sector will be developed in three stages: a pilot phase from 2009 until 2015, an operational period from 2015 until 2020, and expansion afterwards.

The official regulatory framework promises to ensure that the sector will promote ethanol and biodiesel produced from agricultural raw materials appropriate for Mozambique's agricultural and climate conditions (Macauhub 2009). Among the beneficial outcomes expected by the government are: (1) the gradual replacement of fossil fuels; (2) employment generation; (3) the possibility of producing agrofuels and still preventing the spread of monocultures, while considering food security demands and generating income amongst the rural population; and (4) giving the peasant population the opportunity of transforming their agricultural products into biofuels for their energy needs, as well as exporting products with added value (Government of Mozambique 2009). Marcelina Mataveia of the Ministry of Energy explained further the six-point 'Policy and Strategy Principles' in promoting biofuels (Mataveia 2009):

- Inclusiveness - the establishment of business opportunities for the private investors and rural community, including big and small producers.

- Transparency - to ensure that the pricing mechanism is handled in as transparent manner as possible, so overall management of the National Biofuels Program allows for the participation of all stakeholders. 
Table 1. Biofuels projects in Mozambique, late 2008.

\begin{tabular}{|c|c|c|c|}
\hline Name & $\begin{array}{c}\text { Description } \\
\text { (development stage) }\end{array}$ & $\begin{array}{l}\text { Feedstock and target } \\
\text { market }\end{array}$ & Location \\
\hline C3 - Biodiesel & Operational & $\begin{array}{l}\text { Jatropha plantation for } \\
\text { biofuels production and } \\
\text { related activities; } \\
\text { exports contemplated }\end{array}$ & $\begin{array}{l}\text { Bairro de Rumbana, } \\
\text { Maxixe } \\
\text { (Inhambane) }\end{array}$ \\
\hline Deulco & In plantation & $\begin{array}{l}\text { Jatropha plantation for } \\
\text { biofuels production and } \\
\text { related activities; } \\
\text { exports contemplated }\end{array}$ & $\begin{array}{l}\text { Inhassune, District } \\
\text { of Panda } \\
\text { (Inhambane) }\end{array}$ \\
\hline Elaion Africa & In plantation & $\begin{array}{l}\text { Jatropha plantation for } \\
\text { biofuels production and } \\
\text { related activities; } \\
\text { exports contemplated }\end{array}$ & $\begin{array}{l}\text { Localidade de } \\
\text { Savane, Dondo, } \\
\text { Sofala }\end{array}$ \\
\hline Ecomoz & Under construction & $\begin{array}{l}\text { Biofuels production and } \\
\text { related activities }\end{array}$ & $\begin{array}{l}\text { Petromoc } \\
\text { installations (port } \\
\text { cities of Maputo, } \\
\text { Beira and Nacala) }\end{array}$ \\
\hline Adama & $\begin{array}{l}\text { Not yet presented to } \\
\text { Commission for the } \\
\text { Promotion of } \\
\text { Industry (CPI) }\end{array}$ & & Manica \\
\hline $\begin{array}{l}\text { Local community } \\
\text { initiatives }\end{array}$ & $\begin{array}{l}\text { Encouraged by a } \\
\text { presidential speech } \\
\text { on radio }\end{array}$ & $\begin{array}{l}\text { Jatropha for biodiesel and } \\
\text { related activities }\end{array}$ & $\begin{array}{l}\text { District of Moamba } \\
\text { (Maputo } \\
\text { province) }\end{array}$ \\
\hline $\begin{array}{l}\text { CAMEC, Central } \\
\text { African Mining and } \\
\text { Exploration } \\
\text { Company } \\
\text { (ProCana) }\end{array}$ & $\begin{array}{l}\text { Presented to the CPI; } \\
\text { feasibility study }\end{array}$ & $\begin{array}{l}\text { Sugarcane for production } \\
\text { of sugar and refined } \\
\text { sugar, electric power } \\
\text { and fertiliser; exports } \\
\text { contemplated }\end{array}$ & Massingir (Gaza) \\
\hline Haha Projects & & Biodiesel from jatropha & $\begin{array}{l}\text { Provinces of } \\
\text { Nampula or Cabo } \\
\text { Delgado }\end{array}$ \\
\hline Brunellus KFT & & $\begin{array}{l}\text { Ethanol based on maize } \\
\text { and sweet sorghum }\end{array}$ & \\
\hline Madal (Technoserve) & $\begin{array}{l}\text { Operating in the } \\
\text { experimental phase }\end{array}$ & $\begin{array}{l}\text { Coconut, jatropha and } \\
\text { oilseeds for biofuels (as } \\
\text { well as other crops) }\end{array}$ & $\begin{array}{l}\text { Quelimane } \\
\text { (Zambézia) }\end{array}$ \\
\hline Eng. Petiz & $\begin{array}{l}\text { Has } 200 \text { ha planted. } \\
\text { Will deliver } 20,000 \\
\text { tons of sugar cane to } \\
\text { Mafambisse }\end{array}$ & $\begin{array}{l}\text { Sugar for export and, from } \\
2009 \text { onward, } \\
\text { production of ethanol }\end{array}$ & Dondo (Sofala) \\
\hline Girassol Manica & In production & $\begin{array}{l}\text { Sugar cane, sunflower, } \\
\text { jatropha and soya for } \\
\text { ethanol and biodiesel }\end{array}$ & $\begin{array}{l}\text { Sussundenga } \\
\text { (Manica) }\end{array}$ \\
\hline Geralco & $\begin{array}{l}\text { Initial testing at the } \\
\text { existing plantation }\end{array}$ & Jatropha & $\begin{array}{l}\text { Quelimane } \\
\text { (Zambézia) }\end{array}$ \\
\hline Algas & $\begin{array}{l}\text { Research and } \\
\text { development of } \\
\text { algae-based biofuel } \\
\text { production }\end{array}$ & Biodiesel & $\begin{array}{l}\text { Quelimane } \\
\text { (Zambézia) }\end{array}$ \\
\hline $\begin{array}{l}\text { Grupo Moçfer SA } \\
\text { Enerterra }\end{array}$ & Feasibility study & $\begin{array}{l}\text { Jatropha; exports } \\
\text { contemplated }\end{array}$ & \\
\hline
\end{tabular}


Table 1. Continued.

\begin{tabular}{|c|c|c|c|}
\hline Name & $\begin{array}{c}\text { Description } \\
\text { (development stage) }\end{array}$ & $\begin{array}{l}\text { Feedstock and target } \\
\text { market }\end{array}$ & Location \\
\hline Sunbiofuel & & Jatropha & Manica \\
\hline British Petroleum & Feasibility study & & \\
\hline Pete $\mathrm{Nel}$ & Feasibility study & Sugar cane for ethanol & Chimoio (Manica) \\
\hline Somoil & $\begin{array}{l}\text { Small-scale } \\
\text { demonstration } \\
\text { facility }\end{array}$ & & Inhambane \\
\hline COFAMOSA & $\begin{array}{l}\text { Feasibility study to be } \\
\text { funded by the } \\
\text { African } \\
\text { Development Bank }\end{array}$ & Exports contemplated & \\
\hline $\begin{array}{c}\text { Indústria Açucareira } \\
\text { de Moçambique }\end{array}$ & & Sugar cane for ethanol & Maputo, Sofala \\
\hline Principal Energy & Pre-feasibility studies & $\begin{array}{l}\text { Sugar cane and sweet } \\
\text { sorghum for ethanol; } \\
\text { exports contemplated }\end{array}$ & Dombe (Manica) \\
\hline
\end{tabular}

Source: Mozambique, Commission for the Promotion of Industry; additional information is from Econergy International Corporation (2008).

- Environmental and social protection - to provide mechanisms to enhance the environmental and social benefits of biofuels production and use, while avoiding or mitigating any negative impacts.

- Incrementalism - the development of biofuels in the country should be gradual and flexible, permitting all shareholders to develop institutional capacity.

- Fiscal sustainability - the development of the biofuel sector should pose a financial burden on the state that is as short-term as possible, and in the long term it should make a positive contribution in fiscal as well as macro-economic terms.

- Innovation - agriculture and industrial innovation, attracting investment in commercial proven technologies that are new to the country.

It also referred to the duties of different stakeholders involved in the strategy, among which is the duty of the government to support rural communities in the development of their own projects, and to 'guarantee clear and transparent communication with other interest parties $[\mathrm{sic}]$ in matters of general interest and stimulate public dialog and knowledge about relevant matters' (Government of Mozambique 2009: par. 5.2[i]).

How to realise the official goals set by government is of course a different matter. Towards this end, and to date, the most comprehensive and most concrete policy study and recommendation about biofuels in Mozambique is the one prepared by the World Bank and the Embassy of Italy for the Ministry of Agriculture and the Ministry of Energy of Mozambique in 2008. It is a lengthy policy recommendation over 500 pages. For our purposes, we quote some relevant provisions where the Econergy consultants see the potential of biofuels for Mozambique:

For long-haul exports, sugarcane-based ethanol could be cheaper than Brazil's, which can be taken as an international reference, and the price of which has recently decreased from earlier highs due to rapidly growing output (similarly to that of US ethanol), though Mozambique's potential to secure competitive freight costs would depend on volumes. If ocean freight were to be discounted, however, sugarcane-based ethanol produced in Mozambique could be competitive against Brazil's for regional exports in 
Southern Africa. Mozambican ethanol, therefore, could be competitive in domestic markets (provided the fuel tax is waived, and oil prices remain above US\$60 per barrel: prices lower by $20 \%$ would lead to parity with imported gasoline), as well as in regional and overseas markets. A national bioethanol programme, therefore, should encourage large-scale ethanol production for export, but it should be primarily based on expected volumes for the domestic and regional markets (Econergy International Corporation 2008, pp. 30-31).

A projected 450,000 ha biofuels programme in the country is expected to generate the following outcomes (Econergy International Corporation 2008, pp. 33-34):

- A decrease in imports of petroleum-based fuels, representing about a 5\% decrease in the total cost of imported fuel as projected for 2008 .

- A decrease of tax revenues (import duty, tax on fuel and value added tax (VAT)).

- An increase of corporate income tax levels, halving the loss in revenues attributable to decreased fuel imports.

- The creation of some 150,000 jobs.

- Longer-term improvements in the balance of trade resulting from exports of ethanol, vegetable oil and biodiesel.

- Increases in traffic at the country's major ports, with associated port revenues, as well as increased business for transportation companies.

At the same time that policy frameworks and feasibility studies are being carried out at the national level, a number of corporate-led ventures have started to be set up across the country, promoting both ethanol and biodiesel. Table 1 offers a summary of the major initiatives under way in Mozambique by the end of 2008.

The Mozambican government has framed the biofuels initiative within the context of interrelated concerns: energy, environment, land, employment, livelihoods and food, among others. It is within this broad national context that we decided to undertake a closer examination of the initial phase in establishing the ProCana sugarcane ethanol project, the largest of its kind in Mozambique, with 30,000 ha of land allocated.

\section{The case of ProCana}

In an interview with two of the authors, Izak Holtzhausen, CAMEC's country manager in Mozambique and manager of ProCana, ${ }^{1}$ explained the main features of the project as follows: ProCana started identifying suitable lands for sugar cane production in 2006, and successfully applied for land allocation of 30,000 ha under a long-term lease of 50 years, renewable. ProCana was heavily investing in drip irrigation and would use 108 billion gallons of water/year taken from the nearby Massingir Dam. At the time of our field visit ProCana had already cleared 830 ha of land and had already planted 25 ha with six varieties of sugar cane as a nursery. The idea was to plant up to 800 ha in the first phase and subsequently scale up to 5000 ha every year for the subsequent three years so that it would be in full operation by 2011. It promised to employ up to 7000 local people during its full operation. The ethanol plant was supposed to be ready at the end of 2010 so that the ethanol production at commercial scale could start in 2012. ProCana planned to produce $300,000 \mathrm{~m}^{3}$ of ethanol a year and was convinced that it would be able to compete with Brazilian ethanol. According to their official plan, $80 \%$ of ProCana's ethanol would be marketed across the border to Southern African Development Community (SADC) countries, but mainly to South Africa. The main line of product would be fuel for the transport sector, but would also provide the basis for 
ethanol-based plastics for South African industry. The project was projected to help increase the income of local people by up to five times more than the national poverty line income. A critical examination of the ProCana case gave us a less rosy picture, and provides critical insights that are relevant to similar biofuel and land deal cases beyond Mozambique.

\section{Contested notion of marginal land}

One of the key assumptions that underpins the current advocacy for biofuels is the availability of under-utilised land in which to produce crops for biofuels (World Bank 2010). It is generally assumed that 'land-abundant' countries will become key hosts to global biofuels production. Many large countries in sub-Saharan Africa are assumed to be in this category. Mozambique is one country where such a claim has been made and advocacy advanced. The desired implication of this assumption is that production of crops for biofuels in land abundant countries will not undermine food production and supply for local communities, and will not have any negative consequences to existing livelihoods of the rural poor (Borras et al. 2010). In these claims, we see both implicit and explicit assumptions that with land abundance, production for biofuels can be located in marginal areas, without negative impact on the social and agroecological environment. It is in this context that the notion of 'marginal' lands has accompanied the advocacy for biofuels. The term 'marginal lands' (or wastelands, unused, under-utilised or idle lands) is a catch-all phrase used to refer to lands that are not fully utilised in economic terms, i.e., not fully vibrant spaces for full-scale commercial activities, and usually assumed to be geographically remote and without any vital infrastructure. It is also commonly assumed that these marginal lands are lands without inhabitants; that these are 'empty' lands. It is along this line that the Mozambican president has declared the country's official stand on the issue, as quoted above.

Mozambique is a land-abundant country. This is one official argument used by the Mozambican government in aggressively promoting biofuels because the latter will not purportedly undermine the food supply of the local communities and country. It is therefore important to conduct a critical examination of what kind of land ProCana received for its sugarcane plantation to produce ethanol.

This generalisation on the abundance of land masks the situation in Gaza province, which is one of the driest in Mozambique, and periodically subjected to droughts and floods. Part of Gaza province lies in the rain shadow of nearby Madagascar during trade winds in the rainy season (November to February), while another part receives some rain from winds derived from the South Atlantic, in the rain shadow of the Drakensberg mountains in neighbouring South Africa. For the most part, consequently, the province is semiarid, with low rainfall. Because the province is also very low lying, it is also subject to the flooding of the major catchments, especially during a La Niña event. Recently, the most serious floods were those which occurred in 2000 and which devastated the provincial capital Xai Xai (Christie and Hanlon 2001).

Given the poor rainfall in the southern provinces of Mozambique, the Portuguese authorities agreed that the South African coal and gold mines could recruit workers south of the 22nd parallel. Soils were allowed to become degraded, except perhaps during the period of war (1982-1992) during which time many people had to flee the war-torn areas. With low rainfall and degraded soils, the main agricultural activities included cattle-raising and forestry. At times the extreme levels of poverty have meant a great deal of subsistence upon traditional and wild foods (Alexander et al. 1998, pp. 5-6). 
The Massingir district, in which ProCana was granted land, benefits from higher rainfall than other parts of the Gaza province. The huge extension of the Massingir dam on the Rio dos Elefantes river was completed in 2006, adding to the attractiveness of the area for agriculture. However, problems of seepage, and the threat of collapse during floods have meant that the dam has had to be rehabilitated (African Development Bank 2009, p. iv). Nevertheless, in offering ProCana land in the area, officials of the Ministry of Agriculture are likely to have known about its strong agricultural potential relative to other parts of the province.

The ProCana land is not under large-scale commercial use, in the capitalist notion of full commercial and efficient land use. At least three key agricultural economic activities by the local communities are found in the said space, namely, livestock raising by cattle herders, charcoal production and subsistence farming. The land is traditionally utilised, in this sense, in a very extensive way. Hence, based on a capitalist definition, this land indeed is 'marginal', but not completely. There are three features of the ProCana land allocation that may not be the usual features of any generally accepted definition of marginal land. The ProCana land is: (1) very close, and some parts of it adjacent, to the newly opened, huge Massingir dam; (2) adjacent/close to the Rio dos Elefantes which is a key source of irrigation water; and (3) along a major provincial highway.

What we found out is that, contrary to the general claims that lands allocated for biofuels would not compete with local food production and would be located in marginal lands, the ProCana plantation was located on prime agricultural land with great potential for food production. And while the existing extensive farming would provide some evidence to the mainstream claim of 'marginal lands', it should also remind us that traditional livelihood strategies in many southern African countries include extensive crop and livestock farming. Perhaps for outsiders a large parcel of land dedicated to livestock raising may be considered marginal, but certainly this is not how the cattle herders would view such lands. Finally, as indicated, key infrastructures are available in this parcel of land. Intensive and highly productive family farming has great potential in this area. Locating the ProCana plantation in this particular site therefore puts the key assumption and official declarations of the government about the real intentions on biofuels in serious question. If biofuels are to be located in truly marginal lands, ProCana should not have been allocated land in what appears to be prime agricultural land in Mozambique.

ProCana's 30,000 ha of land was allocated under a long-term lease of 50 years, which was renewable. ProCana would not be able to get a title deed for the land even after 50 years. However, ProCana could get title deeds for the infrastructure after 50 years. This would mean an effective control over land resources after 50 years because control over infrastructure cutting across an expanse of land would constitute control over land. And so, while on paper the ProCana land allocation would not violate the Constitutional provision on land ownership, it is possible that the institutional lease arrangement would eventually lead to de facto land ownership (i.e., 'effective control') by a foreign company.

\section{Land grabbing as water-grabbing}

The discourse around biofuels and water is closely linked to the discourse around biofuels and marginal lands. That the rush for lands to be used for biofuels production is, in many settings and on many occasions, essentially a competition for water resources, rarely enters the official discourse on biofuels and global land grabbing. Most of the feedstocks for biofuels, including jatropha that is thought to grow in semi-arid and waterless conditions, are, to varying extents, dependent on irrigation. The initial promise of 'non-irrigated' jatropha 
was indeed one of the key attractions to this project, at least in the beginning. But for jatropha, this assumption is proving not to hold true. Jatropha plants may survive on dry lands, but are unlikely to be productive at a level that is commercially viable. Fertilisers and water are key for commercially viable jatropha farming. This has been seen in many recent experiences in Kenya, India, Philippines, Indonesia - and Mozambique (e.g., Ariza-Montobbio et al. 2010; Hunsberger 2010). If water is needed by a crop like jatropha, it is needed even more for crops such as sugarcane.

Taken within this context, it is not surprising what we have found out in the ProCana plantation. The allocated land, as mentioned above, is very close to the Massingir dam and adjacent to the Rio dos Elefantes. When we asked the general manager of ProCana about any major risk in their investment, he quickly and explicitly mentioned the possible conflict around the issue of what volume of water from the Massingir dam could be released to be used as irrigation for the ProCana plantation, as against the main allocation to produce electricity. In its full capacity, the dam has the potential to irrigate 90,000 ha of land, while the total arable land in Massingir district is more than 70,000 ha. ${ }^{2}$ But the actual releasing of water for irrigation is a contested issue; generating electricity for export remains the main priority.

In situations where there would be drought (and it is likely), the government would first honour its commitment to generate electricity for export to South Africa and for the domestic industrial sector (that is also partly owned by transnational companies). Any remaining water from the dam was likely to be committed by the government to ProCana - as ProCana claimed that they had received the assurance from the national government that their irrigation needs would be protected at all times. Bioenergy Africa claims that

To ensure that cane production is not compromised by other potential users, ProCana has obtained a guarantee from the Mozambican government to enable it to use up to 750 million cubic metres a year with a water licence being granted once the final design for the extraction of the water has been submitted.(Agencia de Informacão de Moçambique 2008)

ProCana would need 407 million $\mathrm{m}^{3}$ of water per year to irrigate its sugarcane plantation. But is there a sufficient supply of water from the Massingir dam and the Rio dos Elefantes?

In a simulation study based on existing and projected water usage in the area, van der Zaag et al. (2010, p. 837) conclude that there is

insufficient water all envisaged irrigation developments amounting to 73,000 ha. There is sufficient water for only $60 \%$ of that figure. It is evident that if ProCana would use all the water allocated to it ... then the downstream water users will face water shortages ....

The downstream users to be severely affected include subsistence farmers along the Rio dos Elefantes, small farmers in Chokwe, as well as livestock herders in the general area.

Hence, if this plan on water (re)allocation was carried out, there is no way that it would not have negative consequences for the farming activities, existing and future, by smallscale farming households in the area. It is very likely that such (re)allocation of water resources, especially in relatively dry places like southern Mozambique, would undermine the autonomy and capacity of local communities to produce their own food for their consumption. However, a state guarantee of a constant water supply to the sugar cane plantation is probably unsustainable in the light of the variability of rainfall in the area and the insecurity of water flow into the dam. 


\section{Disruption in livelihoods}

One of the selling points of biofuels in the global South is that it will spur and promote livelihoods and employment among the rural poor in host communities. This is said to be so by promoting schemes such as contract farming and generation of employment. And so, in remote rural communities where there are no significant commercial economic activities, this will be a welcome development. It is precisely in this context that the Mozambican promotion of biofuels has been framed.

In an interview with the general manager of ProCana, in the first phase of the venture (by August 2009) which involved clearing, nursery set-up, building houses, and so on, more than 150 local people were already employed. ${ }^{3}$ ProCana had committed itself to recruiting only local people, now and in the future. However, according to the manager, the actual number of people to be employed could not be determined before the actual full operation. The number would depend on what kinds of regulatory laws the national government would pass related to environmental, labour and social safety regulations. For example, if the government were to ban burning of cane and impose strict labour standards, then ProCana felt it could opt for a mechanised plantation set-up. But if the national government were not to impose a ban on cane burning and were flexible about labour standards, then ProCana could opt for a non-mechanised plantation set-up. The latter would potentially be more labour intensive, estimated by ProCana at 5000-6000 workers, while the former would accommodate fewer at around 3000-4000 workers. But the Massingir District Agriculture Head, Engr. Mauricio Huo, was optimistically counting on a ProCana promise to employ 7000 workers when it was due to be in full operation, by 2011 (a high estimate based on a labour-intensive cane-burning technique). ${ }^{4}$ This employment issue would only be resolved in the medium-term, and not in the immediate future.

This situation clearly reveals that the main starting point of ProCana, just like any capitalist venture, is profit - not people and the environment: anything can be adjusted as long as profit is secured. The claim about setting up ventures so that people will have employment struck us as plain rhetoric. This particular case of ProCana seems to us to fit one important trend in dispossession-accumulation processes, i.e. when, in Tania Li's formulation, corporations need rural poor people's land but not their labour - and the dispossessed cannot be absorbed in any economically productive sectors of the economy (Li 2011). of course some labour will be hired, but whether the plantation enclave will be able to absorb as much labour as it dispossessed/displaced is another issue; and based on the industrial-monocrop model of farming, it is likely that the venture will absorb less labour than what is being claimed officially.

In addition, we interviewed an older man who lives inside the land which had been allocated to ProCana and is among those being asked to leave the community where he was born, and where his ancestors had lived. We asked him about the potential benefit of having employment in the plantation. He gave us two interrelated responses: (1) he thought that only the younger, mostly skilled, men would be hired in the plantation, and (2) that he has been happy and satisfied with his subsistence farming and charcoal production in his community, his and his parents' livelihoods. But Massingir District Agriculture Head Engineer Huo thought it important that the local communities stop their charcoal-based livelihoods and become employed in the sugarcane plantation; this will stop the chopping down of forests for charcoal-making (although of course setting up sugar cane plantation requires chopping down the entire forest in the 30,000 ha area). ${ }^{5}$ Meanwhile, there are also deep concerns about the reorganisation and rerouting of the areas for livestock grazing. Large parts of the ProCana land allocation are, historically, 
areas and routes for livestock grazing by cattle herders. Due to the ProCana project, the pastoralists and their grazing areas and routes were being relocated, while some of their traditional practices about livestock raising were changed to becoming 'semi-sedentary'.

Finally, in addition to the 30,000 ha that ProCana will directly operate under an industrial monocrop set-up, the company and the district government also encouraged farmers that would be relocated to adjacent and nearby places to produce sugarcane and food crops for ProCana's needs through outgrowing schemes. ProCana was helping and subsidising small-scale farmers around its plantation to grow $20 \%$ food crops and $80 \%$ sugarcane on their own lands. Any ProCana reliance on outgrowers would place these small farmers under the company's regime without providing them with secure income, legal protection, or infrastructural support, while being able to utilise their land, as demonstrated in many contract growing schemes worldwide historically (Little and Watts 1994).

ProCana's estimate was that under their proposed scheme, a small-scale farmer could have an income of US\$12,000 per year, which is five times greater than the Mozambican average income. There are 20,000 and 70,000 ha (re)allocated lands around the ProCana plantation, ${ }^{6}$ and these lands were being planned to serve the ProCana business interest. Hence, in essence, had ProCana's scheme been successful, it might have provided the company with effective control of up to 100,000 ha of land, three times more than its official land allocation. This would have been more land than ProCana could have irrigated, and relied to a great extent on the outgrower farmers taking the risks of relying on rain-fed sugar cultivation.

\section{Competing notions of land}

The corporate biofuels initiative considers land as the new oil wells where fuel can be pumped out regularly. In this perspective, land is a scarce economic resource. The most efficient (re)allocation and use of land becomes a critical consideration. It is from this fundamental assumption that the value of land, and of biofuels produced from the land, is calculated. In this context, land as a place where people live seems to be not given an important consideration. When and where this happens, dislocation, and even dispossession, of people become a usual outcome of land-based development intervention, such as in many extractive industries like mining, and indeed, biofuels. In this context, land is considered simply as one of the economic factors of production.

The ProCana case is a good example of the competing views between the view considering land simply as one of the economic factors of production on the one hand, and the view that looks at land from a more multidimensional perspective starting with land as a place to live.

According to the information provided by ProCana, five local communities were consulted: Zulu, Chitar, Banga, Mahiza and Mocatini. Unfortunately, the authors were unable to find out the exact number of people currently living on the lands allotted to the ProCana project and who would be affected by relocation. If we take the number of families in one village (61) as average, at least 360 families would be affected. The actual figure should be indeed much higher given the fact that this seems to be one of the smallest villages in the area.

Meanwhile, those who have always lived inside the ProCana land allocation were being, and would be, relocated. ProCana intended to set up an industrial, monocrop sugarcane plantation. There was no room for communities to stay inside the 30,000 ha contiguous area. Thus, these communities would be resettled outside the ProCana land allocation. In an interview with one older man inside the community, he said: 
I was born here. I make my living farming here and from the forest products. My parents were born here. They died here. In fact we have cemeteries here. Now they want us to leave. Our cemeteries will be destroyed. I don't want to abandon my parents. We will not leave.

Other testimony indicated that those settled on the river stood a strong chance of being displaced in order to service the guarantee that ProCana's estate would be contiguous and would have access to irrigation.

\section{Competing claims and conflict over land (re)allocation}

To complicate things even further, ProCana land, at least partially, encroached on land that was allocated for the resettlement of inhabitants of the Limpopo National Park to the north of Massingir dam. This park, constituted from former hunting reserves, borders on South Africa's Kruger National Park and Zimbabwe's Gona-rhe-Zhou National Park. Together, the three adjacent national parks were established as part of a trans-frontier conservation area. It was envisaged that the fences between the parks would be dropped, enabling the excess elephant population of the Kruger to find an extended range, mostly in Mozambique.

South Africa's conservation policy, since the early twentieth century, has been to exclude human settlement from occurring inside its national parks, resulting in a number of cases of forced removal. In the case of Mozambique, the proclamation of the Limpopo National Park included a resident population within park boundaries. While the land had mostly been abandoned during the harsh conditions of the civil war, many former residents and war refugees later resumed their livelihoods on the land once peace had been established. With the transnational pressures to create the Limpopo National Park, few local inhabitants were consulted about their futures. However, as the plans for the national park progressed, more communities were encroached upon by wild animals, and their crops and children were in danger of being trampled by the growing elephant population.

Instead of resolving such problems, and attempting to incorporate local people into helping with park management, the Mozambican park authorities were persuaded by their South African counterparts to run the parks exclusively for animal habitation and push for the relocation of the resident human communities. Funding for this was made available for this from a German government agency, the KfW Bankengruppe (formerly the Kreditanstalt für Wiederaufbau). After complex negotiations, a number of communities were relocated to lands along the Rio dos Elefantes, to the south of the protected area. It has to be noted that while Mozambique claims to have one of the most progressive land laws in the region that protests the rights of the rural poor (Land Law of 1997; Tanner 2002) which is clearly one of the legacies of the Mozambican revolution and is part of a protracted debates and policymaking initiatives around land issues (O'Laughlin 1995). Lunstrum (2010, p. 349) explains that 'although the land law protects land use rights outside the park via land-use certificates and titles, it simultaneously exempts the space of the park from having to grant or acknowledge these rights'.

Some informants claimed that the Ministry of Tourism, the authority in charge of the park, had negotiated with the more robust Ministry of Agriculture to provide land for this resettlement. The Ministry of Agriculture had promised the Ministry of Tourism that it would secure lands in Massingir district. Nevertheless, the allocation was proposed for the site but apparently not formally demarcated, although communities were given the general understanding that the land would be for their use, and communities were 
transferred to the area. Later ProCana applied for a land-lease for this area, and this was granted, seemingly outbidding the Ministry of Tourism.

The affected communities did not just suffer the relocation from their initial land in the park, but were faced with encroachment on the resettled land by ProCana. Since ProCana had enjoyed special treatment from government, including guaranteed water allocation, the displaced communities found it extremely difficult to challenge the extent of ProCana's encroachment onto what communities thought of as land under their own control. In negotiations, ProCana tried to urge resettled inhabitants to abandon their riverine plots (on which ProCana wanted to establish sugar cane) and be relocated again to lands further afield. Since ProCana appeared to enjoy powerful official support, it was problematic for the affected peasants to protest. There was also little intervention on the part of the German agency that had funded the removals.

Limited support for the displaced communities came from the churches including the Christian Council of Mozambique. Reverend Dinis Matsolo, its general secretary, showed an active interest in the plight of the displaced communities. He explained to the authors that nine communities (Mavoza, Massingir Velho, Bingo, Makavene, Chibatana, Matinga, Machaule, Machamba, Ximange) still lived inside the park and that only one had already been resettled. The Lutheran and the Catholic Churches had been supporting these communities since 1994.

The authors had the opportunity to enter into the Limpopo National Park and interviewed members of the Mavoza community, one of the nine communities which would have to be resettled. There are 345 families (2626 persons) who live in Mavoza. ${ }^{7}$ Community leaders told the authors that the park authorities proposed to them that they be resettled on the lands which are now controlled by ProCana, but they were not happy with this proposal since they regarded the lands they live on in the park as better. The communities started identifying other lands but the park authorities have not been sufficiently supportive. At the time of the interview, the community leaders preferred to stay in the park and intended to request the government to change the boundaries of the park.

\section{Transparency and accountability}

The great promise of corporate-driven biofuels has partly led to the current global scramble for land, especially in the global South. There were widespread reports of the rural poor being relocated or dispossessed in the process. Many powerful international development institutions, including the World Bank, have therefore argued for greater transparency and accountability in the land acquisition processes. In what they call a 'win-win' formula in the current global land rush, advocates of this position are calling for a 'code of conduct', transparency and accountability being key to this. Some are more specific: they call for 'free, prior, and informed consent' of the affected communities, while others are particularly advocating for community-based negotiation processes. In whatever scenario, they call for clearer laws, rules and regulations about consultation of and participation by the local communities to ensure that the main interests of the affected local communities are protected and promoted (Deininger 2011; see De Schutter 2011, Li 2011, Borras and Franco 2010 for an initial critique).

Mozambique is one of the few countries in the world with a very clearly progressive national land law that is supposed to protect and promote the interest of the rural poor. The features of the 1997 law include: land being publicly owned, every household who needs land has its own allocation, and no land shall be taken from any household or community without prior consultation with and consent by the affected communities (Article 
12). Considering this progressive law as well as the character of Mozambique as a land abundant country, it may not be difficult to believe that indeed the interest of the rural poor will not be undermined by any corporate-driven biofuels project. Yet, our initial findings lead us to a different preliminary conclusion.

There was indeed some kind of community consultation about the ProCana project, although it seems that only the local elites and elders were actually consulted, some of whom have personally endorsed the mega-project in their communities. However, instead of putting into the agenda the fundamental issue of whether or not the local communities accept the ethanol project and if so, under what terms, it seems to us that the consultation processes were generally limited to the question of the terms of relocation - the who, what, where, how and when - from the ProCana allocated lands to somewhere outside. Earlier documentation initiatives about this process, as well as our own meetings with the affected communities and discussions with some affected individuals, both those who have traditionally lived inside the ProCana land allocation and those who were expelled from the Limpopo National Park, have suggested the same findings. This has put the entire consultation process in serious question, and the issue of accountability in a cloud of doubt (also Vermeulen and Cotula 2010).

But what the ProCana experience also tells us is that ensuring transparency and accountability in a political economic setting marked by imbalances in power relations (between state and community, state bureaucrats and ordinary people, local elites and poor people, powerful companies and poor people, and so on) will not automatically result in outcomes that favour the poor. And so, we should distinguish between an administrative and technical view of consultation with poor people on the one hand and a political perspective on the same process. The former is apolitical, the latter takes on power relations seriously. What happened in ProCana seems to be the former, and so without much meaningful impact on the rural poor.

\section{Competing notions of development}

The original discourse on biofuels in the North, especially in the European Union, was centred on the claim about reducing greenhouse gas emissions especially by the transport sector that is responsible for about a third of total greenhouse gas emissions in the world. This was soon discredited. Not completely abandoning its greenhouse gas savings claim, the European Union has brought in two more reasons for promoting biofuels: energy security for the European Union and rural development for both the European Union and the producing countries in the global South (Franco et al. 2010). Meanwhile, national governments in the global South have not remained passive actors in the biofuels initiative. Many of these national governments have autonomously pursued mega-dreams and mega-project plans for biofuels, impelled by their desire to save and even generate foreign exchange earnings, as well as provide employment in their countryside.

The Mozambican national government has been very clear in its intentions for biofuels. It wants biofuels to be produced both for international and domestic energy markets. The material basis for the latter seems to be compelling: while Mozambique is a land abundant country, roughly two-thirds of the country does not have electricity, and only $7 \%$ of the countryside has electricity. Forests are being cleared to produce charcoal, the country's main household fuel, for cooking. Most rural children are unable to study at night. The country also needs to save, if not generate, foreign exchange.

However, while it might generate some foreign exchange, the ProCana sugarcane ethanol project does not respond to resolving the question of rural energy poverty in 
Mozambique, a goal that underpins the official policy of the national government. In an interview with the general manager of ProCana, we were informed that the corporate plan is to produce ethanol and market $80 \%$ of this across the border to SADC countries, mainly to South Africa. The manager also informed us that their planned main line of product is not biofuel for the transport sector, but ethanol-based plastics for South Africa.

What then are the implications of this actual corporate plan for the official claims and aspirations of the Mozambican national government? There are several, and all these lead us to re-examine critically the fundamental question of 'what development and for whom?' It is clear that the ProCana project does not respond to the national government official claims of pursuing biofuels project for domestic energy needs. The $20 \%$ ethanol that is supposed to be destined for the domestic market is unlikely to be used for electrification, as it may be more economically viable to sell it to the transport sector. If this is so, it means catering to the needs of a small urban-based middle class and other elite who have cars - and certainly not the $93 \%$ of the rural poor who are literally 'power-less'. But this is not a surprise at all. It fits quite squarely with the general trend of the Mozambican energy policy. The country produces an enormous amount of energy from coal, natural gas and hydro power - but exports almost all of this, leaving the country in its current state. As Diamantino Nhampossa of the União Nacional de Camponeses (UNAC), Mozambique, in an interview with the authors, said:

It is not a question of whether Mozambique has the capacity to produce energy, because we produce so much that it is likely that we can be nationally self-sufficient if we use all the coal and hydro power domestically. It is a question of the fundamental orientation in generating power: to generate profit for transnational companies or to generate fuel for the Mozambican people's needs? ${ }^{8}$

\section{The dubious nature of the investment}

CAMEC, the company investing in the ProCana project, had as its principal investor a rich Zimbabwean entrepreneur named Muller Conrad ('Billy') Rautenbach, who held diversified interests in numerous African countries, as well as Europe and Asia. Reputedly close to President Robert Mugabe, he was blacklisted in the European Union and United States in 2008 and 2009, respectively, for supplying funds to ruling party ZANU-PF to keep the incumbent president in power. CAMEC had paid US\$100 million for platinum concessions in Zimbabwe which had been confiscated from Anglo Platinum by the government in 2008. Opposition leaders claimed that this money had helped fund the election violence in the same year (Thorneycroft 2009a). As a result of being on the sanctions list, Rautenbach cannot physically enter the European Union and the United States or trade with their nationals. Effectively this means that the assets of CAMEC were frozen by the European Union.

Rautenbach was not only a beneficiary of his political connections in Zimbabwe, but also in the Democratic Republic of Congo (DRC). During the civil war in the DRC, Mugabe had sided with Kabila, and for his military support, received a stake in the government's decrepit and bankrupt mining company Gecamines. Rautenbach was made head of the company, and boosted cobalt production in the mineral rich province of Katanga. However, a series of clashes with Kabila led to his expulsion from the DRC. After Kabila's death he was allowed to return, and engineered the sale of Gecamines' cobalt assets to his own CAMEC (Thorneycroft 2009b). 
Mugabe's government also allowed Rautenbach to become the recipient of a 300,000 ha cattle farm in the Nuanetsi area of Zimbabwe, left in trust to the nation by former leader Joshua Nkomo for the development of small-scale agriculture. Rautenbach had demanded the eviction of the small farmers resident on the ranch. 'You cannot do anything to me. I am a powerful man', said Rautenbach to local farmer Terry Mkowa, facing eviction, an interview with whom was aired in a broadcast on the UK television broadcaster Channel 4 (Hartley 2009). The Zimbabwean press reported that 100,000 ha of the Nuanetsi ranch would be devoted to production of sugarcane for ethanol, aimed at reducing Zimbabwe's fuel bill. However, water experts claimed that there was insufficient water in the area to sustain so much sugarcane (Sunday Mail 2009).

For a decade, Rautenbach was wanted on criminal charges in South Africa. Having formed a company in Botswana to manufacture Hyundai vehicles, the company subsequently was liquidated, and he was charged for defrauding South African customs and tax services, and accused of stealing 1300 vehicles from Hyundai. Forced to leave South Africa as a wanted man in 1999, he returned in 2009 to pay a plea bargain fine of US\$50 million for his crimes to be overlooked.

In September 2009, CAMEC sold $95.4 \%$ of its shares to the Eurasian Natural Resources Company, a privatised formerly public resources firm in Kazakhstan accounting for 5\% of that country's gross domestic product. ${ }^{9}$ The rump of the company was said to be restructuring and is no longer trading under the CAMEC brand. The likelihood of it being able to trade had come under question. In the context of European Union and United States sanctions, and global recession, it had become difficult to raise the funds that it needed to operate ProCana, and in the end, squandered the support that it had initially received from the Mozambican state.

The numerous WikiLeaks revelations of kickbacks and directorships provided to President Armando Guebuza by direct foreign investors in Mozambique indicates the broad levels of corruption in the upper reaches of the state, which may account for the special treatment provided to CAMEC in the early years of the ProCana project (Afrique Avenir 2010).

\section{Conclusions}

An older man in one of the villages inside the ProCana allocated land underscored some issues that are at the heart of this contested development process. ${ }^{10}$ Among others, he emphasised to us the following:

There are 61 families in this village. We were born in this village, and so were our parents who
were buried in our community cemetery. We produce food crops and we have cattle... Yes, we
were consulted by ProCana and the local government about the relocation site and the new
grazing area. But we were not convinced. We did not agree. As far as I know other villages
also did not agree. We are trying to gather other villages to come together and discuss the
matter. We are worried that we will be forcibly evicted from our land despite our opposition.
The local government and ProCana people told us there is no irrigation in our land, and that we
will be relocated to a place where there are irrigation facilities. Why not put those irrigation
facilities here, in our land, if they really wanted to help us? We can even grow sugarcane
for ProCana, but we have to stay in our land.... We have what we need. This land is ours.
We will not leave.

Key drivers of biofuels from the transnational corporate world (oil, car, biotechnology, agro-industrial sectors, among others), international development agencies and national 
governments have claimed a 'three-win' scenario out of the biofuels initiative: helping to address pressing environmental problems via greenhouse gas savings, attaining energy security in order to maintain the current pattern of economic production and consumption in the North, while instigating economic growth and development in the global South. The principal targets to host biofuel production are land abundant countries, such as Mozambique.

The emerging literature on this theme suggests that these assumptions and projects are too optimistic and are fundamentally flawed. First, evidence suggests that greenhouse gas savings are not going to be achieved, and, in fact, greenhouse gas emissions are going to increase, with corporate clearing of forests to pave the way for industrial and monocrop biofuel plantations. In some biofuel feedstocks the energy balance is such that their cultivation may also be increasing greenhouse gas emissions. Second, the fundamental starting point of the mainstream key drivers of biofuels is how to maintain the current patterns of economic production and consumption in the world, especially in the North. This includes the ever increasing use of cars. This is a problem, since simply looking for ways to fuel the current pattern of economic production and consumption without critically re-examining the very nature and character of the same economic production and consumption will not lead to any resolution of the environmental and energy problem. Finally, while in aggregate terms economic investments and development may register in some locations in developing countries, it is unlikely that it will contribute in any significant way to solving the problems of poverty, inequality and socio-political exclusion of the rural poor. Many of these land investments are in the form of large-scale industrial monocrop plantations that require more land and water and less labour. Hence, under certain conditions, promoting biofuels in places marked by poverty, inequality and socio-political exclusion might contribute to increasing the same social, economic and political problems.

The ProCana ethanol project in Mozambique displayed the actual and potential problems raised above. First, clearing the second-growth forest in the ProCana land allocation, and replacing it with industrial-monocrop sugarcane plantation (with the probable later use of labour-intensive, cane-burning techniques) will not lead to greenhouse gas savings, but to greater net greenhouse gas emissions. Second, the planned ethanol production geared for export feeds into and strengthens the dominant model of economic production and consumption. Finally, between the massive dislocation, or even dispossession, of thousands of people in and around the ProCana land allocation and the employment promised to some, the net impact on the lives and livelihoods of the local population, on balance, is likely to be negative for the local communities. A broader view on this question will include the cost of lost opportunity for the local villagers. For example, the government would redirect a major portion of its farm irrigation water allocation from the Massingir dam from its commitment to small-scale farmers and cattle herders to ProCana - in effect financially subsidising ProCana sugarcane production. This begs the question: what if the government uses the same enormous farm irrigation water to service farmers and pastoralists directly in and around the area? The latter is likely to have a greater multiplier effect in terms of socio-economic livelihood impact than redirecting the dam water to a corporate industrial monocrop sugarcane plantation that will produce ethanol for export. The current water use (re)allocation in effect would render the full use of the Massingir dam as geared for outside Mozambique, while $93 \%$ of the rural poor Mozambicans remain 'power-less' and majority of farmers and pastoralists have no access to irrigation water. ${ }^{11}$

Relocated, and faced with further threats of dispossession and their livelihoods disrupted, many of the rural Mozambicans affected by the ProCana sugarcane ethanol 
project risked the loss of their autonomy and capacity to produce their own crops for subsistence and for the market. These had come under severe pressure historically especially in the context of colonial agricultural production system, the recent war, the earlier attempts at large-scale state farmlands - and were even further undermined by the ProCana plans. Investment in agriculture in Mozambique is, without doubt, urgent and necessary largely because as Cramer and Pontara (1998, p. 110) explain: 'poverty in rural Mozambique is associated with market-isolation and the lack of off-farm income sources' (also Wuyts 2001). But the ProCana case is exactly what Li has warned us about: a large-scale land-expropriating and labour-expelling investment. Thus, from a longer view we ask: then, what kind of development is this, and for whom? UNAC's Diamantino Nhampossa was categorical about their position: 'No to agrofuels for export. Yes to agrofuels for domestic consumption as long as its production does not undermine food sovereignty. ${ }^{12}$ But in the end, ordinary people are not interested whether their products are used as food, or feeds, or fuel, as long as their fundamental interests as people and farmers are protected - as clearly stated by the man we interviewed inside the ProCana land allocation quoted at the beginning of this concluding section.

In October 2009, the main investor in ProCana, the London-based CAMEC, announced that it would not continue to invest in biofuel projects, as it planned to focus on its main investment portfolio, which is mining. This announcement was followed two months later by the statement issued by the Mozambican government that it was stopping and closing the operation of ProCana, and is now seeking new investors that can develop the same 30,000 ha of land. But regardless of how the biofuel project (ProCana-led or not) unfolds in the future, the socio-political processes that have already unfolded to date have provided us with key insights about the politics of biofuels, land and the rural poor. These will be relevant insights for the rural poor in the Massingir district of the Gaza province in Mozambique, in Mozambique in general - and elsewhere with similar socio-political and economic agrarian conditions.

\section{Acknowledgements}

We would like to thank the Transnational Institute and FoodFirst Information and Action Network for the funds that facilitated our series of field work in Mozambique. We also thank UNAC (National Farmers' Union of Mozambique) for facilitating our fieldwork in Maputo and in the Gaza province. We also thank the anonymous reviewers, as well as Gary Littlejohn and Janet Bujra, for very helpful comments and suggestions.

\section{Notes on contributors}

Saturnino M. Borras Jr is Associate Professor at the International Institute of Social Studies in The Hague; Adjunct Professor at China Agricultural University; Fellow of the Transnational Institute and of FoodFirst; and Co-Coordinator of the Land Deal Politics Initiative (http://www.iss.nl/ldpi). $\mathrm{He}$ is co-editor of Transnational Agrarian Movements Confronting Globalization (with Marc Edelman and Cristobal Kay).

David Fig is a political economist and environmental sociologist. He is based in Johannesburg, South Africa. Recent publications include work on nuclear energy, acid mine drainage, corporate behaviour, food security, electricity policy, agrofuels and technological choices.

Sofía Monsalve Suárez is a human rights activist and works as the Land Programme Coordinator of FoodFirst Information Action Network (FIAN) International. She also coordinates the working group on agrarian reform and territory of the International Planning Committee for Food Sovereignty (IPC). 


\section{Notes}

1. Interview at Massingir, Gaza province, 26 August 2009.

2. Interview with Engr. Mauricio Huo, Massingir District Agriculture Head, Massingir, 25 August 2009.

3. Interview with ProCana General Manager, Massingir, 26 August 2009.

4. Interview, 25 August 2009.

5. Interview, Massingir, 25 August 2009. The contradiction in this is that the government is raising the issue of deforestation caused by charcoal-making, but would allow the complete clearing of 30,000 ha of forested lands for a sugarcane monocrop plantation.

6. Interview with ProCana General Manager, Massingir, 26 August 2009.

7. Interview, Mavoza, 25 August 2009.

8. Interview, Maputo, 24 August 2009.

9. See http://www.ask.com/wiki/Eurasian_Natural_Resources_Corporation?qsrc=3044 [Accessed 20 January 2011].

10. The person requested not to be identified, along with the name of his village. Interview, Massingir District, inside the ProCana land allocation, 26 August 2009.

11. For a broader critique of the current Mozambican policy on renewable energy, see Hankins (2009).

12. Interview, Diamantino Nhampossa, Maputo, 24 August 2009.

\section{References}

African Development Bank, 2009. Project appraisal report: Massingir dam emergency rehabilitation project. Tunis: African Development Bank.

Afrique Avenir, 2010. Mozambique leader linked to drug trafficking, money laundering purchase commission, WikiLeaks, 10 December. Available from: http://www.afriqueavenir.org/en on [Accessed 29 December 2010].

Agencia de Informacão de Moçambique, 2008. Biofuel project wants Mozambican labour, Agencia de Informacão de Moçambique, 28 November. Available from: http://allafrica.com/stories/ 200811280929.html [Accessed 27 November 2009].

Alexander, J., Littlejohn, G., and McGregor, J.A., 1998. Preface: Special issue on Mozambique. Journal of Southern African Studies, 24 (1), 5-6.

Ariza-Montobbio, P., Lele, S., Kallis, G., and Martinez-Alier, J., 2010. The political ecology of Jatropha plantations for biodiesel in Tamil Nadu, India. Journal of Peasant Studies, 37 (4), 875-897.

BiofuelsDigest, 2008. Mozambique president sets biofuels objectives: no diversion of food production, all refining in Mozambique, [online]. BiofuelsDigest, 29 January. Available from: http://www.biofuelsdigest.com/blog2/2008/01/29/mozambique-president-sets-biofuels-objectivesno-diversion-of-food-production-all-refining-in-mozambique/ [Accessed on 27 November 2009].

Borras, S., Jr and Franco, J.C., 2010. From threat to opportunity?: problems with the idea of a 'code of conduct' for land grabbing. Yale Human Rights and Development Law Journal, 13 (1), 507-523.

Borras, S., Jr, and McMichael, P., and Scoones, I., 2010. The politics of biofuels, land and agrarian change an editorial introduction. In: S. Borras, Jr, P. McMichael and I. Schoones. The politics of biofuels, land and agrarian change. London: Routledge, 1-18.

Christie, F. and Hanlon, J., 2001. Mozambique and the great flood of 2000. Oxford: James Currey.

Cotula, L., Vermeulen, S., Leonard, R., and Keeley, J., 2009. Land grab or development opportunity?: agricultural investments and international land deals in Africa. London: IIED.

Cramer, C. and Pontara, N., 1998. Rural poverty and poverty alleviation in Mozambique: what's missing from the debate? Journal of Modern African Studies, 36 (1), 101-138.

De Schutter, O., 2011. How not to think of land grabbing: three critiques of large-scale investments in farmland. Journal of Peasant Studies, 38 (2), 249-279.

Deininger, K., 2011. Challenges posed by the new wave of farmland investment. Journal of Peasant Studies, 38 (2), 217-247.

Econergy International Corporation, 2008. Mozambique biofuels assessment: final report, Report prepared for the Ministry of Agriculture and the Ministry of Energy of Mozambique under contract to the World Bank and Embassy of Italy, Maputo. 
Franco, J., Levidow, L., Fig, D., Goldfarb, L., Hönicke, M., and Mendonça, M.L., 2010. Assumptions in the European Union biofuels policy: frictions with experiences in Germany, Brazil and Mozambique. Journal of Peasant Studies, 37 (4), 661-698.

Gillon, S., 2010. Fields of dreams: negotiating an ethanol agenda in the Midwest United States. Journal of Peasant Studies, 37 (4), 723-748.

Government of Mozambique, 2009. Resolution 22/2009, 21 May 2009. Maputo: Government of Mozambique.

Hankins, M., 2009. A renewable energy plan for Mozambique. Maputo: Justiça Ambiental.

Hartley, A., 2009. Channel 4, Dispatches, 'Bankrolling Mugabe', broadcast 27 July.

Hunsberger, C., 2010. The politics of Jatropha-based biofuels in Kenya: convergence and divergence among NGOs, donors, government officials and farmers. Journal of Peasant Studies, 37 (4), 939-962.

Li, T.M., 2011. Centering labour in the land grab debate. Journal of Peasant Studies, 38 (2), 281-298.

Little, P. and Watts, M., eds., 1994. Living under contract: contract farming and agrarian transformation in Sub-Saharan Africa. Madison, WI: University of Wisconsin Press.

Lunstrum, E., 2010. Mozambique, neoliberal land reform and the Limpopo National Park. Geographical Review, 98 (3), 339-355.

Macauhub, 2009. Mozambique: government approves national biofuels policy and strategy, [online]. Macauhub, 25 March. Formerly available from: http://www.macauhub.com.mo/en/news. php?ID=7110 [Accessed 27 November 2009].

Mataveia, M., 2009. Biofuel policy and strategy for Mozambique. Presentation given at the Global Energy Conference, New York, NY, USA, 14-15 May 2009. Available from: http://www. globalbioenergy.org/.../Mataveia_-_GBEP_CSD_side_event_140509.pdf [Accessed on 27 November 2009].

McMichael, P., 2009. A food regime genealogy. Journal of Peasant Studies, 36 (1), 139-170.

O'Laughlin, B., 1995. Past and present options: land reform in Mozambique. Review of African Political Economy, 22 (63), 99-106.

Richardson, B., 2010. Big Sugar in southern Africa: rural development and the perverted potential of sugar/ethanol exports. Journal of Peasant Studies, 37 (4), 917-938.

Sunday Mail, 2009. Megabucks project. Sunday Mail (Harare), 19 July.

Tanner, C., 2002. Law-making in an African context: The 1997 Mozambican land law. Legal Papers No. 26. Rome: Food and Agricultural Organization (FAO).

Thorneycroft, P., 2009a. Fugitive Rautenbach permitted to farm agricultural land in Zimbabwe. The Star (Johannesburg), 3, August.

Thorneycroft, P., 2009b. Rautenbach free to live south of Limpopo. Business Report (Johannesburg), 27, September.

Van der Zaag, P., Juizo, D., Vilanculos, A., Bolding, A., and Post Uiterweer, N., 2010. Does the Limpopo River Basin have sufficient water for massive irrigation development in the plains of Mozambique? Physics and Chemistry of the Earth, 35, 832-937.

Vermeulen, S. and Cotula, L., 2010. Over the heads of local people: consultation, consent and recompense in large-scale land deals for biofuels projects in Africa. Journal of Peasant Studies, 373, 899-916.

Wilkinson, J. and Herrera, S., 2010. Biofuels in Brazil: debates and impacts. Journal of Peasant Studies, 37 (4), 749-768.

World Bank, 2010. Rising global interest in farmland: can it yield sustainable and equitable benefits? Washington, DC: The World Bank.

Wuyts, M., 2001. The agrarian question in Mozambique's transition and reconstruction. UNU WIDER Discussion Paper No. 2001/4. Helsinki: United Nations WIDER. 